\title{
Diffuse myocardial fibrosis in children after heart transplantation
}

Eugenie Riesenkampff ${ }^{*}$, Steven C Greenway ${ }^{1}$, Paul Kantor ${ }^{1}$, Helen Holtby', Rajiv Chaturvedi', Shi-Joon Yoo ${ }^{1}$, Mike Seed ${ }^{1}$, Andreas Greiser ${ }^{2}$, Lars Grosse-Wortmann ${ }^{1}$

From 17th Annual SCMR Scientific Sessions

New Orleans, LA, USA. 16-19 January 2014

\section{Background}

It is unclear if children after heart transplantation (HTX) are at risk for developing increased myocardial fibrosis. Diffuse myocardial fibrosis can be estimated by myocardial longitudinal relaxation (T1) times.

\section{Methods}

Twenty cardiovascular magnetic resonance (CMR) studies in 17 patients after HTX (mean age 13.2 years, range 1.2 - 17.4 years, 9 female) were analysed retrospectively and compared to CMR studies in nine healthy controls

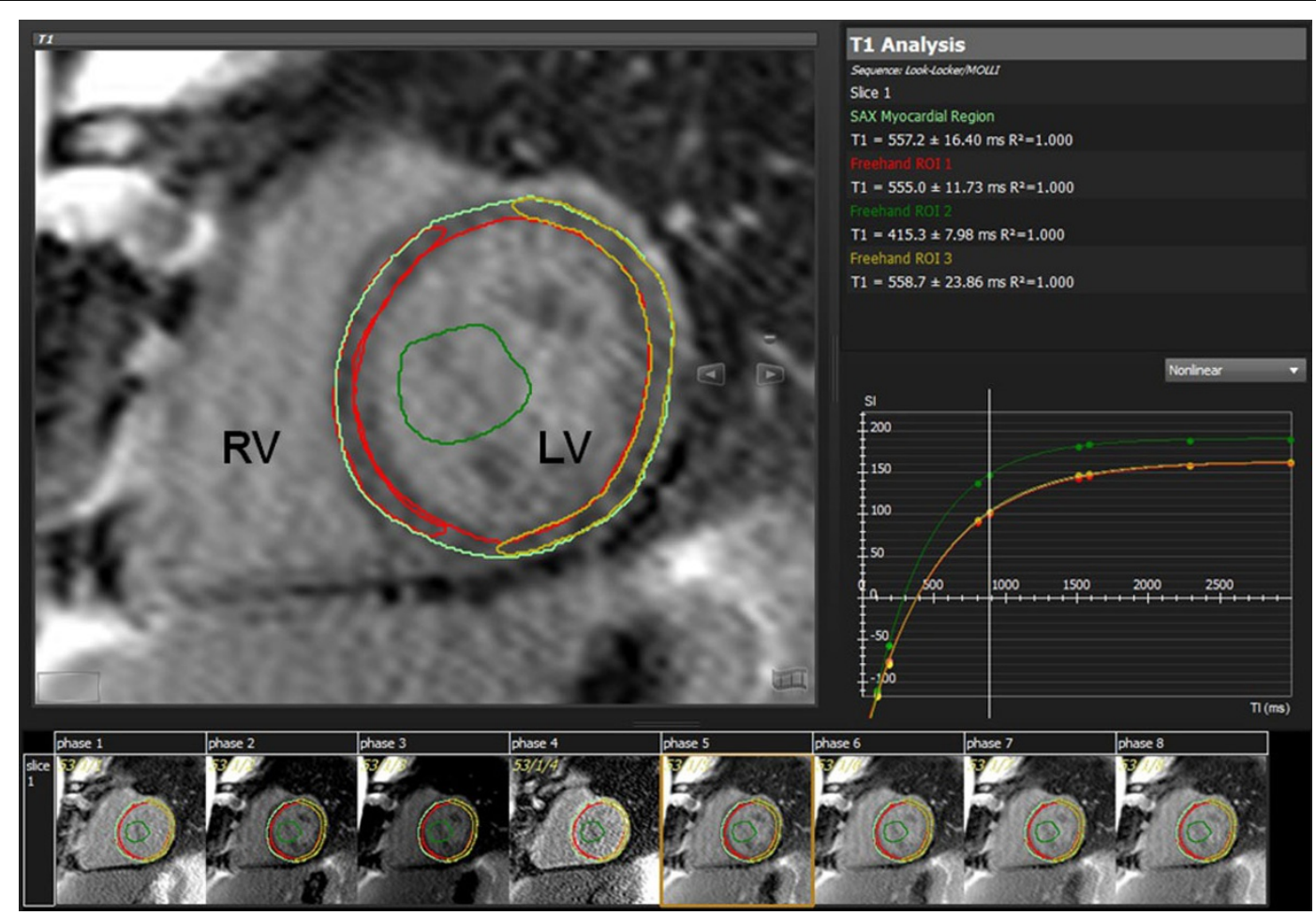

Figure 1 Tissue longitudinal relaxation (T1) kinetics, derived from a short axis image in a patient after heart transplantation. $L V=$ left ventricle, $\mathrm{RV}=$ right ventricle. Light green = complete LV myocardium, red = septal myocardium, yellow $=$ free wall LV myocardium, dark green $=$ blood pool.

\footnotetext{
'Labatt Family Heart Centre in the Department of Paediatrics, Hospital for
} Sick Children, Toronto, Ontario, Canada 
(mean age 12.1 years, range 9.2 - 16.7, 4 female). Patients with clinically significant rejection were excluded. T1 measurements were performed at a single mid-ventricular short axis slice orientation before and $>10$ minutes after the application of $0.2 \mathrm{mmol} / \mathrm{kg}$ gadopentetate dimeglumine (Gd) in the interventricular septum (IVS), LV lateral wall and the complete LV myocardium (Image). The tissue-blood partition coefficient was calculated as a function of the ratio of $\mathrm{T} 1$ change of myocardium as compared to blood.

\section{Results}

Pre-contrast T1 times before the application of Gd were significantly higher in HTX patients compared to controls (LV lateral wall $977 \pm 40 \mathrm{msec}$. versus $923 \pm 12 \mathrm{msec}$., $\mathrm{p}<0.001$; IVS $1008 \pm 32 \mathrm{msec}$. versus $974 \pm 21 \mathrm{msec}$., p < 0.005; complete LV myocardium $992 \pm 34$ msec. versus $951 \pm 16$ msec., $\mathrm{p}<0.005)$, whereas the reduced post-contrast T1 times in the HTX patients showed a trend towards being shorter than in controls but failed to reach statistical significance. Tissue-blood partition coefficients were elevated in patients after HTX in the LV lateral wall $(0.45 \pm 0.06$ versus $0.40 \pm 0.03, \mathrm{p}<0.01)$ and the complete LV myocardium $(0.47 \pm 0.06$ versus $0.43 \pm 0.03$, $\mathrm{p}<$ $0.05)$. The difference in the IVS failed to reach statistical significance $(0.48 \pm 0.06$ versus $0.45 \pm 0.03, \mathrm{p}=0.122)$.

\section{Conclusions}

Diffuse fibrosis is present in children after HTX as evidenced by pre- and post-contrast myocardial T1 mapping. The technique may be suitable for the detection of early signs of adverse remodeling after HTX.

\section{Funding}

This study was partly funded by the Labatt Family Heart Centre, Witchell Fellowship, and by Siemens.

\footnotetext{
Authors' details

${ }^{1}$ Labatt Family Heart Centre in the Department of Paediatrics, Hospital for Sick Children, Toronto, Ontario, Canada. ${ }^{2}$ Healthcare Sector, Siemens AG, Erlangen, Germany.
}

Published: 16 January 2014

doi:10.1186/1532-429X-16-S1-P135

Cite this article as: Riesenkampff et al:: Diffuse myocardial fibrosis in children after heart transplantation. Journal of Cardiovascular Magnetic Resonance 2014 16(Suppl 1):P135.
Submit your next manuscript to BioMed Central and take full advantage of:

- Convenient online submission

- Thorough peer review

- No space constraints or color figure charges

- Immediate publication on acceptance

- Inclusion in PubMed, CAS, Scopus and Google Scholar

- Research which is freely available for redistribution

Submit your manuscript at www.biomedcentral.com/submit 